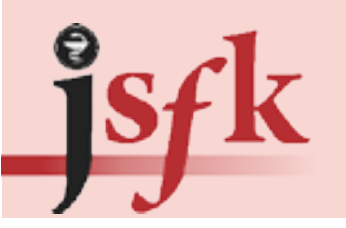

Jurnal Sains Farmasi \& Klinis (p- ISSN: 2407-7062 | e-ISSN: 2442-5435)

diterbitkan oleh Ikatan Apoteker Indonesia - Sumatera Barat homepage: http://jsfkonline.org

\title{
Kajian Penggunaan Antibiotik pada Pasien Sepsis dengan Gangguan Ginjal
}

\author{
(Study of Antibiotic Using on Septic Patients with Kidney Disorder)

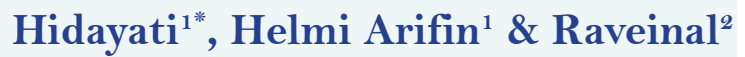 \\ ${ }^{1}$ Fakultas Farmasi, Universitas Andalas, Limau manis, Padang \\ ${ }^{2}$ Fakultas Kedokteran, Universitas Andalas, Padang
}

\section{Keywords: \\ antibiotic; septic; renal disorder; dose adjustment; antibiotic quality.}

Kata kunci: antibiotik; sepsis; gangguan ginjal; penyesuaian dosis; kualitas antibiotik.
ABSTRACT: Prospective observational study was conducted to investigate antibiotic using, by evaluating clinical pharmacokinetic and antibiotic quality on septic patient with kidney disorder in Interne Department at Hospital X. Septic patients with kidney disorder treated with antibiotic for 4 months. The evaluated antibiotic are excreted by kidney mainly. The clinical aspects of evaluation are kinds of antibiotic, dosage, frequency, period of treatment, and clinical drug interaction. The evaluation of antibiotic quality used Gyssens method. Total respondens were 40 patients, treated with 8 kinds of antibiotic. Among 8 of them, there were 5 antibiotic which were excreted mainly by kidney. From five antibiotics, it was found that the accurate dosage adjustment on 29 patients (74,3\%), and unproperly adjustment in 10 patients (10,25\%) that adjust upper individual dosage that calculate pharmacokinetically. There were five interactions that clinically significant. The evaluation of antibiotic using qualitatively by Gyssens method found that 4 patients (10\%) as incomplete therapy/VI category, two patients (5\%) were ineffective category IVa, I patient (2,5\%) as unsafe category IVb, 9 patients (22,5\%) as inappropriate dosage adjustment, and 23 patients (57,5\%) as appropriate antibiotic category 0 . Conclusion: Using antibiotic that mainly excreted by kidney in septic patients with kidney disorder, generally doesn't show bad impact in kidney of patient.

ABSTRAK: Telah dilakukan kajian observasional secara prospektif terhadap penggunaan antibiotik meliputi aspek farmakokinetika klinik dan kualitas antibiotik secara kualitatif pada pasien sepsis dengan gangguan ginjal di Rawat Inap Penyakit Dalam Rumah Sakit X. Pasien sepsis dengan gangguan ginjal ini diterapi dengan antibiotik selama 4 bulan. Antibiotik yang dievaluasi adalah yang ekskresi utamanya di ginjal meliputi jenis antibiotik, dosis, frekwensi, lama penggunaan, dan interaksi yang bermakna klinis. Evaluasi antibiotik secara kualitatif menggunakan metode Gyssens. Total pasien berjumlah 40 orang, diterapi dengan 8 jenis antibiotik dan diantaranya ada 5 antibiotik diekskresi utama melalui ginjal. Dari 5 jenis tersebut, ditemukan penyesuaian dosis dengan tepat pada $(\mathrm{n}=29 ; 74,3 \%)$ dan penyesuaian dosis yang tidak tepat $(\mathrm{n}=10 ; 25,7 \%)$ yang melebihi dosis individual yang dihitung secara farmakokinetik. Terdapat 5 jenis interaksi yang bermakna secara klinik. Evaluasi pemakaian antibiotik secara kualitatif dengan metode Gyssens, diperoleh kategori pasien tidak lengkap/VI (N=4; 10\%), kategori tidak efektif/IVa $(\mathrm{n}=2 ; 5 \%)$, kategori tidak aman/IVb $(\mathrm{n}=1 ; 2,5 \%)$, kategori spektrum tidak sempit/ IVd ( $\mathrm{n}=1 ; 2,5 \%)$, kategori dosis tidak tepat/IIa ( $\mathrm{n}=9 ; 22,5 \%)$, dan kategori bijak/tepat/o ( $\mathrm{n}=23$; $57,5 \%$ ). Dari penelitian ini dapat disimpulkan bahwa secara umum penggunaan antibiotik yang diekskresikan sebagian besar melalui ginjal tidak memperlihatkan dampak yang buruk pada fungsi ginjal pasien.
${ }^{*}$ Corresponding Author: Hidayati (Fakultas Farmasi, Universitas Andalas, Limau manis, Padang)

email:www_ynt@yahoo.co.id
Article History:

Received: 24 Oct 2014

Published: 1 May 2016
Accepted: 27 Oct 2014

Available online: 19 Aug 2016 


\section{PENDAHULUAN}

Sepsis merupakan kondisi klinis yang disebabkan oleh respon sistemik tubuh terhadap infeksi. Secara global insiden sepsis mengalami peningkatan dengan angka kematian yang terus bertambah. Hampir sepertiga pasien yang dirawat di ICU Hospital Español adalah sepsis [1]. Sepsis telah menyebabkan kematian terbanyak di rumah sakit RSCM Jakarta [2]. Insiden sepsis di RSUP DR. M. Djamil Padang juga telah meningkat hampir 50\% pertahunnya sejak tahun 2010 hingga Agustus 2013 yaitu masing-masingnya sebanyak 351 pasien; 512 pasien; 757 pasien; dan 734 pasien dengan sepsis sebagai diagnosa utama.

Dalam pengobatan infeksi sepsis di Rumah Sakit X, sering digunakan antibiotik kombinasi secara empiris. Agar antibiotik dapat digunakan secara tepat dan efektif, maka perlu dilakukan evaluasi dan pengawasan dalam penggunaannya [3]. Kajian penggunaan antibiotik secara kualitatif dilakukan dengan metode Gyssens yang telah divalidasi [4]. Penggunaan antibiotik empiris yang memadai dan tepat waktu adalah landasan pengobatan sepsis disamping optimalisasi awal hemodinamik pasien [5,6,7]. Rekomendasi SSC menyarankan pemberian antibiotik segera saat 1 jam pertama setelah terdiagnosa syok sepsis dan sepsis berat [8].

Sepsis sebagai respon sistemik terhadap infeksi dapat mempengaruhi hampir setiap sistem organ. Gagal ginjal akut adalah komplikasi yang paling sering pada sepsis. Pasien sepsis dengan gagal ginjal akut memiliki angka kematian yang tinggi [9]. Sekitar 35-50\% dari kasus gagal ginjal akut di ICU dapat disebabkan oleh sepsis [10]. Gagal ginjal akut terjadi sekitar 19\% pada pasien dengan sepsis moderat, sekitar 23\% dengan sepsis berat, dan sekitar 51\% dengan syok sepsis disertai hasil kultur darah positif [11]. Seiring dengan berkembangnya progresifitas AKI/
Acute Kidney Injury pada pasien yang dirawat di rumah sakit, angka kematian berkisar antara 25\% sampai 35\% [12]. Penelitian terhadap 185 pasien sepsis di ruang ICU Hospital Ghent University menyimpulkan bahwa AKI berkembang pada $16,2 \%$ pasien sepsis dan $70 \%$ diantaranya membutuhkan terapi renal. Tingginya kejadian AKI juga ditandai dengan serum kreatinin yang akan meningkat pada hari pertama sepsis (>1 mg/ dl dan $\mathrm{pH}<7,3)$ yang dikarenakan oleh terjadinya sindrom capillary leak/kebocoran kapiler sistemik yang berakibat pada hipovolemia intravaskular dan ketidakstabilan hemodinamik [13].

Sebagian besar obat yang larut air dieksresikan dalam jumlah tertentu dalam bentuk utuh melalui ginjal [14]. Akumulasi dan toksisitas dapat meningkat dengan cepat apabila dosis tidak disesuaikan pada pasien yang mengalami penurunan fungsi ginjal [15]. Penyesuaian regimen dosis obat dapat membantu meningkatkan keamanan obat. Metode yang direkomendasikan dalam mengatur penyesuaian dosis adalah dengan mengurangi dosis, memperpanjang interval dosis atau kombinasi keduanya [16].

Penelitian prospektif Ikbal (2014) mengenai tinjauan akumulasi levofloksasin pada pasien CKD stadium V di IRNA Penyakit Dalam RSUP DR M. Djamil Padang dengan metode elektroforesis kapiler menyimpulkan bahwa terjadi akumulasi pada hari ke-15 dengan Dmaks 1250 mg. Terjadi perpanjangan waktu paruh pasien dari 6-8 jam pada ginjal normal menjadi 34,65 jam. berdasarkan metode Gusti-Hayton perlu penurunan loading dose dari 250-500 mg yang biasa diberikan klinisi menjadi 77-171 $\mathrm{mg}$ dan diperoleh pengaturan maintenance dose sebesar 96,216 mg/hari. Namun, perpanjangan waktu paruh bisa disebabkan oleh komorbiditas yang cukup tinggi pada pasien CKD stadium V. Selain itu dengan metode elektroforesis kapiler juga, penelitian Oviadita \& Andria (2013) menyimpulkan bahwa setelah 
pemberian seftriakson $2 \mathrm{~g}$ /hari terjadi akumulasi seftriakson pada pasien CKD stadium IV di hari kedua pemakaian dan akumulasi di hari ketiga pemakaian pada pasien CKD stadium V [18]. Berdasarkan hal tersebut maka dirasa perlu dilakukan penelitian mengenai kajian antibiotik pasien sepsis dengan gangguan ginjal yang meliputi aspek farmakokinetik klinik dan evaluasi antibiotik secara kualitatif untuk mencegah terjadinya penurunan fungsi ginjal pasien sepsis terutama terhadap antibiotik yang diekskresikan sebagian besar melalui ginjal.

\section{METODE PENELITIAN}

\section{Rancangan Penelitian}

Penelitian ini dilakukan dengan studi cross sectional. Teknik pengambilan sampel dilakukan secara prospektif dengan metode purposive sampling. Sumber data meliputi rekam medis dan observasi langsung pasien sepsis dengan gangguan ginjal selama bulan Desember 2013 hingga Maret 2014 di IRNA penyakit dalam Rumah Sakit X.

\section{Populasi dan Sampel}

Populasi adalah semua pasien sepsis dengan gangguan ginjal di IRNA Penyakit dalam Rumah Sakit X pada bulan Desember 2013 sampai Maret 2014. Sampel yang diambil adalah infeksi sepsis dengan gangguan ginjal di rawat inap yang memenuhi kriteria inklusi.

\section{Kriteria Inklusi}

Data inklusi sampel yang dipilih adalah semua pasien sepsis dengan gangguan ginjal dan mendapatkan terapi antibiotik di IRNA penyakit dalam Rumah Sakit X selama bulan Desember 2013 hingga Maret 2014.

\section{Kriteria Eksklusi}

Pasien sepsis dengan fungsi ginjal yang normal dan pasien sepsis dengan gangguan ginjal yang tidak kooperatif selama penelitian.

\section{Analisa Data dan Kesimpulan}

Analisa data dilakukan secara deskriptif non analitik dan analisa kualitatif. Data disajikan dalam bentuk tabel dan diagram yang selanjutnya dianalisis dan ditarik kesimpulan.

\section{HASIL DAN PEMBAHASAN}

Perolehan pasien pada penelitian ini adalah sebanyak 40 pasien sepsis dengan gangguan ginjal selama Desember 2013 hingga Maret 2014 di IRNA Penyakit Dalam Rumah Sakit X. Dari total 40 pasien, pasien laki-laki berjumlah 24 orang $(60 \%)$ dan pasien perempuan berjumlah 16 orang $(40 \%)$ dengan usia pasien 45-64 tahun adalah yang terbanyak sekitar 20 pasien (50\%). Berdasarkan derajat kerusakan ginjal didapatkan 23 orang (57,5\%) pasien disertai AKI/Acute Kidney Injury dan 17 orang $(86,96 \%)$ pasien disertai CKD stadium V. Lama rawat inap terbanyak adalah 1-5 hari rawatan sekitar 18 pasien (45\%) dengan resume keluar rumah sakit sebagian besar karena meninggal 25 orang pasien (62,5\%). Dari 40 pasien sepsis dengan gangguan ginjal terdapat 16 pasien $(40 \%)$ telah dilakukan uji kultur kuman atau uji sensitivitas antibiotik dan 24 pasien (60\%) yang tidak dilakukan uji kultur. Diantara 16 pasien yang dilakukan uji kultur terdapat 13 orang pasien positif ditemukan bakteri patogen dan 3 pasien lainnya dengan hasil kultur bakteri patogen yang negatif. Berdasarkan hasil kultur, bakteri gram negatif adalah patogen terbesar pada penelitian ini $(68,8 \%)$ dengan Klebsiella sp sebagai bakteri patogen gram negatif yang terbanyak.

Pasien sepsis dengan gangguan ginjal disertai komorbiditas yang cukup tinggi meliputi: infeksi sal.napas (77,5\%), ISK (20\%), hipertensi (12,5\%), masing-masing $\quad 10 \%$ dengan kardiovaskular, 
gangguan fungsi hati, dan hiperurisemia serta sekitar masing-masing 5\% disertai stroke dan dislipidemia. Penggunaan obat lain yang digunakan secara bersamaan adalah analgetik-antipiretik
(75\%), mukolitik (60\%), multivitamin (52,5\%), antihipertensi (40\%), antidiabetes (32,5\%), dan kortikosteroid (30\%).

Tabel 1. Daftar antibiotik yang digunakan pasien sepsis dengan gangguan ginjal

\begin{tabular}{|c|c|c|c|c|}
\hline No & Golongan antibiotik & Nama antibiotik & Jumlah pasien & Persentase (\%) \\
\hline \multirow[t]{4}{*}{1.} & \multirow[t]{4}{*}{ Sefalosporin } & Seftriakson & 35 & 87,5 \\
\hline & & Seftazidim & 3 & 7,5 \\
\hline & & Sefotaksim & 1 & 2,5 \\
\hline & & Sefoperazon & 2 & 5 \\
\hline \multirow[t]{2}{*}{2.} & \multirow[t]{2}{*}{ Waktu Pemakaian Obat } & Siprofloksasin & 27 & 67,5 \\
\hline & & Levofloksasin & 3 & 7,5 \\
\hline 3 & Karbapenem & Meropenem & 6 & 15 \\
\hline 4 & Makrolida & Azitromisin & 8 & 20 \\
\hline 5 & Anaerob & Metronidazol & 3 & 7,5 \\
\hline
\end{tabular}

Tabel 2. Frekuensi antibiotik yang digunakan pasien sepsis dengan gangguan ginjal

\begin{tabular}{|c|c|c|c|c|c|}
\hline \multirow{2}{*}{ Golongan antibiotik } & \multirow{2}{*}{ Nama antibiotik } & \multicolumn{4}{|c|}{ Stage kerusakan ginjal } \\
\hline & & AKI Rifle R & AKI Rifle I & AKI Rifle F & CKD \\
\hline \multirow[t]{4}{*}{ Sefalosporin } & Seftriakson & 8 & 6 & 4 & 17 \\
\hline & Seftazidim & 2 & 1 & - & - \\
\hline & Sefotaksim & - & - & - & 1 \\
\hline & Sefoperazon & 2 & - & - & - \\
\hline \multirow[t]{2}{*}{ Kuinolon } & Siprofloksasin & 6 & 3 & 4 & 14 \\
\hline & Levofloksasin & 2 & 1 & - & - \\
\hline Karbapenem & Meropenem & 1 & 2 & 1 & 2 \\
\hline Makrolida & Azitromisin & 1 & 2 & 1 & 4 \\
\hline
\end{tabular}

Tabel 3. Perbandingan kesesuaian dosis obat yang memerlukan penyesuaian dosis perhitungan farmakokinetik

\begin{tabular}{|c|c|c|c|c|}
\hline \multirow{2}{*}{ No } & \multirow{2}{*}{ Obat yang digunakan } & \multirow{2}{*}{ Jumlah penggunaan } & \multicolumn{2}{|c|}{ Hasil perbandingan } \\
\hline & & & Sesuai & Tidak sesuai \\
\hline 1. & Siprofloksasin & 27 kasus & 27 kasus & - \\
\hline 2. & Levofloksasin & 3 kasus & - & 3 kasus \\
\hline 3. & Meropenem & 6 kasus & - & 6 kasus \\
\hline 4. & Seftazidim & 3 kasus & 2 kasus & 1 kasus \\
\hline & Jumlah & 39 kasus & 29 kasus & 10 kasus \\
\hline & \multicolumn{2}{|c|}{ Persentase (\%) } & 74,3 & 25,7 \\
\hline
\end{tabular}


Tabel 4. Frekuensi interaksi antibiotik dengan obat lain

\begin{tabular}{|c|c|c|c|c|c|}
\hline No & Obat & $\begin{array}{c}N \\
\text { (pasien) }\end{array}$ & $\begin{array}{c}\text { Persentase } \\
\text { (\%) }\end{array}$ & $\begin{array}{c}\text { Jenis } \\
\text { interaksi }\end{array}$ & Keterangan \\
\hline 1 & $\begin{array}{l}\text { Siprofloksasin } \\
\text { - insulin }\end{array}$ & 7 & 38,8 & $\begin{array}{l}\text { Farmakodi- } \\
\text { namika }\end{array}$ & $\begin{array}{l}\text { Penggunaan bersamaan siprofloksasin } \\
\text { dan insulin bisa meningkatkan resiko } \\
\text { hipoglikemia. Oleh karena itu, perlu } \\
\text { dilakukan pemantauan kadar gula darah } \\
\text { pasien secara rutin }\end{array}$ \\
\hline 2 & $\begin{array}{l}\text { Siprofloksasin } \\
\text { - metil predni- } \\
\text { solon }\end{array}$ & 6 & 33,3 & $\begin{array}{l}\text { Farmakodi- } \\
\text { namika }\end{array}$ & $\begin{array}{l}\text { Penggunaan siprofloksasin dengan } \\
\text { deksametason secara bersamaan dapat } \\
\text { menyebabkan komplikasi muskuloskletal, } \\
\text { oleh sebab itu perlu dilakukan pemantauan } \\
\text { kadar kalsium pasien dan kerusakan } \\
\text { tendon. }\end{array}$ \\
\hline 3 & $\begin{array}{l}\text { Azitromisin - } \\
\text { flukonazol }\end{array}$ & 2 & 11,1 & $\begin{array}{l}\text { Farmakoki- } \\
\text { netik }\end{array}$ & $\begin{array}{l}\text { Penggunaan bersamaan bisa saling } \\
\text { meningkatkan interval QTc. Oleh karena } \\
\text { itu dilakukan pemantauan terhadap irama } \\
\text { jantung dan tekanan darah }\end{array}$ \\
\hline 4 & $\begin{array}{l}\text { Ca glukonas - } \\
\text { amlodipin }\end{array}$ & 1 & 5,5 & $\begin{array}{l}\text { Farmakodi- } \\
\text { namik }\end{array}$ & $\begin{array}{l}\text { Penggunaan bersamaan Ca. Glukonas } \\
\text { bisa menurunkan efek amlodipin sehingga } \\
\text { tekanan darah tetap tinggi. Oleh karena itu, } \\
\text { lakukan pemantauan tekanan darah }\end{array}$ \\
\hline 5 & $\begin{array}{l}\text { Ramipril - } \\
\text { furosemide }\end{array}$ & 2 & 11,1 & $\begin{array}{l}\text { Farmakodi- } \\
\text { namika }\end{array}$ & $\begin{array}{l}\text { Penggunaan penghambat ACE bersamaan } \\
\text { dengan diuretika dapat menimbulkan } \\
\text { hipotensi, hal ini } \\
\text { terkadang dibutuhkan pada pasien } \\
\text { tertentu, tetapi hal ini tetap memerlukan } \\
\text { pemantauan untuk mencegah terjadinya } \\
\text { hipotensi }\end{array}$ \\
\hline
\end{tabular}

Tabel 5. Kualitas penggunaan antibiotik pada pasien sepsis dengan gangguan ginjal berdasarkan kategori Gyssens

\begin{tabular}{|c|c|c|}
\hline Kategori Gyssens & Jumlah & Persentase (\%) \\
\hline Data kurang lengkap/IV & 4 & 10 \\
\hline Kurang efektif/IVa & 2 & 5 \\
\hline Kurang aman/IVb & 1 & 2,5 \\
\hline Spektrum kurang sempit/IVd & 1 & 2,5 \\
\hline Dosis tidak tepat/IIa & 9 & 22,5 \\
\hline Tepat/bijak /o & 23 & 57,5 \\
\hline
\end{tabular}

AKI yang berkembang saat sepsis dipengaruhi oleh keadaan patologis sepsis itu sendiri dimana serum kreatinin akan meningkat pada hari pertama sepsis (>1 $\mathrm{mg} / \mathrm{dl}$ ) karena kebocoran kapiler sistemik sehingga berakibat pada ketidakstabilan hemodinamik dan hipovolemia intravaskular [13]. Dan seiring dengan berkembangnya progresifitas AKI pada pasien yang dirawat di rumah sakit, angka kematian berkisar antara 25\% sampai 35\% [12]. Jadi, pasien yang berumur 45-64 tahun 


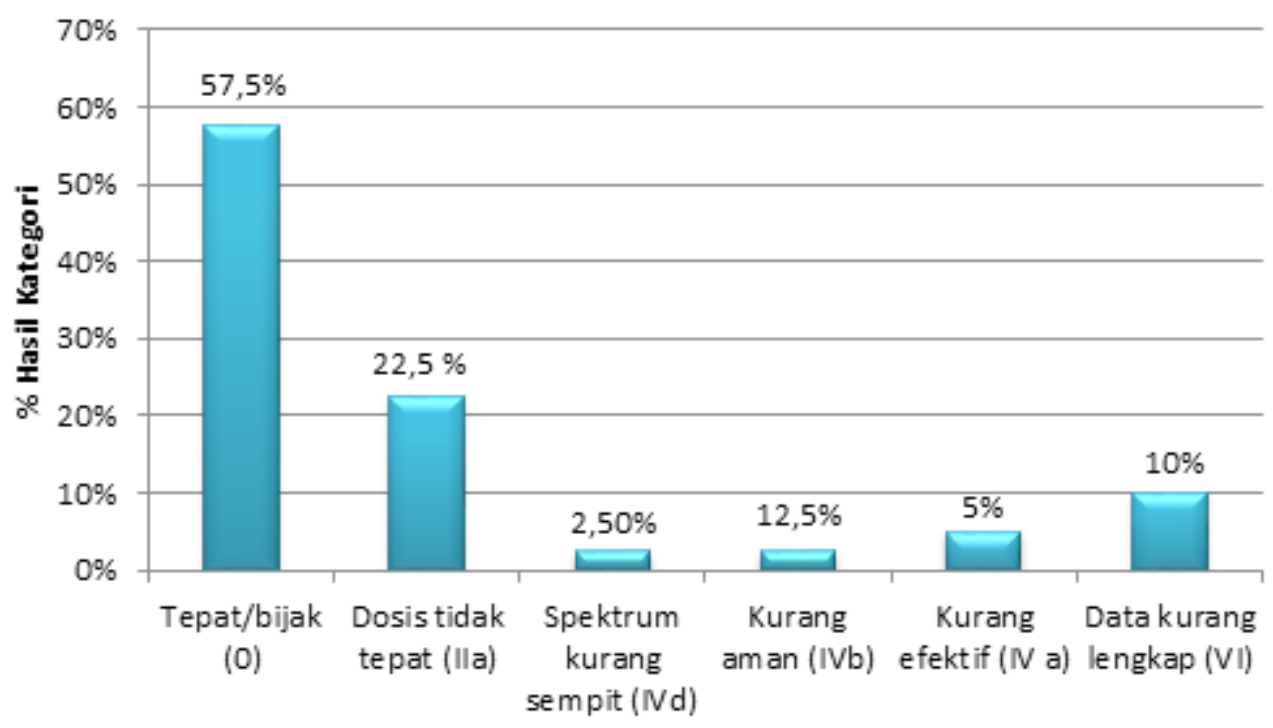

Gambar 1. Hasil penilaian kualitatif penggunaan antibiotik menurut kategori Gyssens pasien sepsis dengan gangguan ginjal

pada penelitian ini rata-rata saat masuk rumah sakit disertai komorbiditas yang tinggi yang telah berlangsung kronis seperti dengan komplikasi diabetes mellitus, ISK, hipertensi, dll. Mekanisme bagaimana dalam usia tersebut mempengaruhi penyakit kronis belum diketahui dengan jelas. Namun, faktor gaya hidup yang kurang sehat, faktor nutrisi yang bermasalah, olahraga yang kurang, beban kerja yang cukup tinggi dan disertai dengan faktor-faktor lainnya yang bisa menurunkan kekebalan sistem imun tubuh kemungkinan bisa menjadi salah satu penyebabnya.

Tingginya angka mortalitas pada penelitian ini pada umumnya karena syok sepsis. Penyebab kematian rata-rata secara umum ICU di USA adalah karena sepsis $20 \%$, sepsis berat $40 \%$, dan syok sepsis $>60 \%$ (Centres for Desease Control and Prevention). Syok sepsis biasanya dimulai dengan nidus infeksi yang melepaskan mikroba dan/ atau satu atau lebih mediator kedalam aliran darah. Banyak mediator seperti histamin, kinin, kebanyakan prostaglandin, lipid A (komponen endotoksin), endorfin, TNF, IL-1 dan IL-2 menimbulkan dilatasi vaskuler, sementara beberapa prostaglandin dan leukotrien menyebabkan vasokontriksi. Vasodilator sistemik menyebabkan resistensi vaskuler sistemik berkurang dan curah jantung rendah atau depresi miokard yang terjadi pada awal syok sepsis. Jika syok sepsis menetap dan tidak tertangani, kombinasi gangguan vaskuler perifer dan depresi miokard menyebabkan kematian. Kematian disebabkan oleh hipotensi yang tidak membaik dan/atau gagal sistem organ. Hipotensi biasanya disertai dengan penurunan pada resistensi vaskuler sistemik yang irreversibel dan berat, depresi miokard akan berkembang dan menyebabkan curah jantung rendah dan memperburuk hipotensi. Kematian dari gagal organ multipel disebabkan oleh insufisiensi fungsi ginjal, hati, otak, dan paru [17].

Dalam penatalaksanaan terapi sepsis, selain optimalisasi hemodinamik pasien juga ditentukan oleh pemilihan dan waktu pemberian antibiotik empiris yang adekuat. SSC merekomendasikan pemberian antibiotik spektrum luas dalam waktu 1 jam setelah diagnosis sepsis ditegakan dan penilaian penggunaan antibiotik setiap hari dengan metode de-ekskalasi. Pendekatan terapi sepsis yang baik dapat menurunkan mortalitas dan morbiditas [8]. 
Pada penelitian ini, penggunaan antibiotik yang diekskresikan sebagian besar melalui ginjal dalam bentuk tidak berubah antara lain seftriakson, seftazidim, siprofloksasin, levofloksasin, dan meropenem. Obat yang perlu penyesuaian dosis berdasarkan fungsi ginjal antara lain: siprofloksasin, levofloksasin, seftazidim, dan meropenem.

Sefalosporin adalah antibiotik terbanyak digunakan pasien dan penyesuaian dosis dilakukan jika GFR $<10 \mathrm{ml} /$ menit dengan dosis maksimal 2 g/hari (RenalDrug Handbook, 2004; 19). Seftriakson mempunyai spektrum aktivitas yang luas bekerja dengan menghambat sintesa dinding sel mikroba dan merupakan salah satu antibiotik yang tidak menstimulusi pelepasan lipopolisakarida sehingga tidak memperburuk keadaaan pasien. Namun tidak bisa diandalkan aktivitasnya terhadap patogen penginfeksi enterobacter Siprofloksasin adalah agen quinolon yang paling aktif terhadap gramnegatif terutama P. Aeruginosa. Siprofloksasin dieliminasi melalui ginjal baik sekresi tubulus atau filtrasi glomerulus. Penyesuaian dosis diperlukan untuk pasien dengan bersihan kreatinin kurang dari $50 \mathrm{ml} /$ menit [20]. Namun pemakaian seftriakson kemungkinan bisa dipertimbangkan pada dosis $1 \times 1 \mathrm{~g} /$ hari daripada dosis $2 \times 1$ karena antibiotik ini tergantung waktu. Selain itu secara farmakoekonomi bisa menghemat biaya operasional pasien saat dirawat di rumah sakit.

Levofloksasin merupakan golongan kuinolon generasi baru yang ditujukan untuk penanganan mikroba S. pneumonia yang merupakan penyebab utama pneumonia yang didapat di rumah sakit. Levofloksasin juga digunakan karena meningkatnya insiden penisilin-resisten $S$. pneumonia [21]. Disamping itu, karbapenem disarankan untuk terapi antibiotik yang resisten kebanyakan patogen. Meropenem aktivitasnya lebih besar terhadap aerob gram-negatif dan aktivitasnya pada gram-positif lebih kecil. Secara signifikan obat ini tidak mengalami degradasi oleh dehidropeptidase ginjal. Dosis buat dewasa $1 \mathrm{gram}$ tiap 8 jam, namun harus dikurangi untuk pasien dengan bersihan kreatinin kurang dari $50 \mathrm{ml} /$ menit. Karbapenem pilihan untuk terapi infeksi Enterobacter, karena kekebalannya terhadap penghancuran oleh b-laktamase yang diproduksi oleh organisme-organisme ini. Selain itu juga aktif terhadap strain pneumokokkus yang resisten penisilin [20].

Kelebihan dosis antibiotik dari rentang terapeutik pada semua kasus pasien penelitian ini yang mendapatkan levofloksasin dan meropenem secara umum tidak memperlihatkan keadaan ginjal pasien yang makin memburuk. Antibiotik ini terutama diekskresi melalui ginjal, akan terakumulasi dalam tubuh pasien yang menderita gangguan fungsi ginjal [22]. Tingginya volume distribusi disebabkan oleh resusitasi cairan yang kemungkinan tidak adekuat sehingga butuh penyesuaian dosis untuk memaksimalkan efikasi dan meminimalkan toksisitas obat. Kondisi ginjal yang memburuk secara patologis yang juga disebabkan oleh sepsis bisa memperpanjang waktu paruh eliminasi obat. Hal ini mengakibatkan obat terakumulasi dalam tubuh. Namun kedua antibiotik tersebut masih memiliki rentang terapeutik yang cukup lebar. Tetapi pemakaian dalam jangka lama bisa memperburuk ginjal pasien. Oleh karena itu walaupun secara klinis tidak memperlihatkan tanda-tanda toksisitas pada penelitian ini namun perlu dilakukan monitoring fungsi ginjal secara berkala terhadap fungsi ginjal pasien.

\section{KESIMPULAN}

Pada penelitian ini pemilihan antibiotik lebih didasarkan pada pola sensitivitas kuman di rumah sakit, fokus penyebab infeksi sepsis, faktor pasien, dan pengalaman klinisi secara empiris. Dari 40 pasien yang memenuhi kriteria inklusi, didapatkan 
pemakaian antibiotik sebanyak 8 jenis antibiotik, dimana 5 jenis diantaranya mempunyai jalur ekskresi utama di ginjal. Dari 5 jenis antibiotik tersebut, ditemukan penyesuaian dosis dilakukan dengan tepat pada 29 kasus (74,3\%) pemakaian antibiotik dan 10 kasus (25,7\%) penyesuaian dosis antibiotik tidak tepat yang melebihi dosis individual jika dihitung secara farmakokinetik dari total 39 kasus pasien. Terdapat 5 jenis interaksi obat yang diberikan pada pasien sepsis dengan gangguan ginjal, akan tetapi beberapa interaksi menguntungkan pada pasien ini meskipun tetap membutuhkan monitoring, adapula interaksi yang dapat meningkatkan resiko yang merugikan pada pasien. Penilaian secara kualitatif antibiotik berdasarkan kategori Gyssens didapatkan penggunaan antibiotik yang tidak lengkap (kategori VI) sebanyak 10\% (4 pasien dari 40 kasus), penggunaan antibiotik yang kurang efektif (kategori IVa) sebanyak 5\% (2 pasien dari 40 kasus), penggunaan antibiotik yang kurang aman (kategori IVb) sebanyak 2,5\% (1 pasien dari 40 kasus), penggunaan antibiotik dengan spektrum yang kurang sempit (kategori IVd) sebanyak 2,5\% (1 pasien dari 40 kasus), penggunaan antibiotik dengan dosis yang tidak tepat (kategori IIa) sebanyak 22,5\% (9 pasien dari 40 kasus) dan antibiotik kategori o yang digunakan secara tepat/ bijak sebanyak 57,5\% (23 pasien dari 40 kasus). Dan selama dilakukan penelitian penggunaan antibiotik secara umum khususnya antibiotik yang diekskresikan sebagian besar melalui ginjal tidak memperlihatkan dampak yang buruk pada fungsi ginjal pasien.

\section{DAFTAR PUSTAKA}

1. Hurtado FJ, Buroni M, dan Tenzi J. (2009). Sepsis: Clinical approach, evidence-based at the bedside. In: Gallo A, editors. Intensive and Critical Care Medicine. Springer-Verlag Italia; $p$. 299-309.

2. Widodo Dewi, Roland A.Tumbelaka. (2010). Penggunaan
Steroid, Dalam Tata Laksana Sepsis Analisis Kasus Berbasis Bukti. Departemen IImu Kesehatan Anak, RS DR Cipto Mangunkusumo, Jakarta: Fakultas Kedokteran Universitas Indonesia. Sari Pediatri;11(6):387-94.

3. Lenski, RE. (1998). Bacterial evolution and cost of antibiotic resistance, USA: Internal Microbial. 1:265-270.

4. Anonim. (2011). Pedoman Pelayanan Kefarmasian untuk Terapi Antibiotik. Kementerian Kesehatan Republik Indonesia. Jakarta

5. Nobre V, Sarasin FP, dan Pugin J. (2007). Prompt antibiotic administration and goal directed hemodynamic support in patients with severe sepsis and septic shock. Curr Opin Crit Care 13: 586-591.

6. Rivers E, Nguyen B, Havstad S, Ressler J, dan Muzzin A. (2001). Early goal directed therapy in the treatment of severe sepsis and septic shock. N Engl J Med 345: 1368-1377.

7. Garnacho-Montero J, Garcia-Garmendia JL, Barrero-Almodovar A, Jimenez- Jimenez FJ, dan Perez-Paredes C. (2003). Impact of adequate empirical antibiotic therapy on the outcome of patients admitted to the intensive care unit with sepsis. Crit Care Med 31: 2742-2751.

8. Dellinger RP, Levy MM, dan Rhodes A. (2013). Surviving Sepsis Campaign: international guidelines for management of severe sepsis and septic shock. Crit Care Med; 41: 580-637.55.

9. Lioudmila V, Karnatovskaia, MD1, dan Emir Festic, MD1. (2012). Sepsis: A Review for the Neurohospitalist, Crit Care DOI: 10.1177/1941874412453338.

10. Cole L, Bellomo R, Silvester W, dan Reeves JH. 2000. For the Victorian Severe Acute Renal Failure Study Group: A prospective, multicenter study of the epidemiology, management, and outcome of severe acute renal failure in a [closed ICU system. Am J Respir, Crit Care Med 162: 191-196.

11. Schrier RW, Wang W. (2004). Acute renal failure and sepsis. N Engl J Med 351:159-16954.

12. Anaizi Nasr. (2007). Drug therapy in kidney desease. Rochester Institute of Technology

13. Hoste EA, Lameire NH, dan Vanholder EC. (2003). Acute renal failure in patients with sepsis in a surgical ICU; Predictive factors, incidence, comorbidity, and outcome. J Am Soc Nephrol 14:1022-1030.

14. Bauer, Larry A. (2008). Applied clinical pharmacokinetics (2nd ed.). USA: Mc. Graw Hill Medical Companies. Inc.

15. Uchino S, Kellum JA, dan Bellomo R. 2005. Acute Renal Failure in Critically III Patients: A Multinational, Multicenter Study. JAMA 294:813-818

16. Munar MY, Singh Harleen. (2007). Drug dosing adjustment in patients with chronic kidney disease, American Family Physician; 75:1487-1496.

17. Parrilo Joseph E. (1999) Syok, Dalam Harrison prinsip-prinsip ilmu penyakit dalam (edisi 13), Jakarta: Buku Kedokteran EGC. vol 1 hal 218-223

18. Oviadita S. Putri. (2013). Tinjauan akumulasi seftriakson dari data urin menggunakan elektroforesis kapiler pada pasien gangguan fungsi ginjal stadium IV di bangsal interne RSUP DR. M. Djamil Padang. Padang: Skripsi Sarjana Fakultas Farmasi, 
Universitas Andalas.

19. Ashley Caroline, Currie Aileen. (2004). Renal Drug Handbook (Third edition). Radclihffe Publishing. United Kingdom.

20. Katzung G. Bertram. (2008). Farmakologi Dasar dan Klinik (Edisi 8). Alih bahasa oleh Bagian Farmakologi Fak. Kedokteran Univ. Airlangga. Jakarta: Salemba Medika.

21. Dipiro. (2009) Pharmacotherapy Handbook Ed. (6th ed.) USA; The McGraw-Hill Companies.
22. Setiabudi Rianto. (2007) Farmakologi Terapi dan Klinik Ed V, Departeman Farmakologi dan Terapeutik FKUI. Jakarta.

23. Ikbal Yenni B. (2014) Tinjauan akumulasi levofloksasin pada pasien gangguan fungsi ginjal stadium lima dengan metode elektroforesis kapiler di IRNA Penyakit Dalam RSUP DR M. Djamil Padang, Skripsi Sarjana Farmasi. Padang: Universitas Andalas. 